\title{
JALE YILMABAŞAR VE SEÇİLİ SERAMİK DUVAR PANOLARI ÜZERİNE BİR DEĞERLENDİRME
}

\author{
Öğr.Gör.Dr. Bengütay HAYIRSEVER 1
}

\section{Özet}

Mimari mekânlarda kullanılan seramik duvar panoları, yapıya ayrı bir değer ve estetik katmaktadır. Jale Yılmabaşar'ın çalışmış olduğu iç ve dış mekân seramik duvar panoları, çağdaş Türk seramik sanatının önde gelen eserlerindendir. Seramik panolar, Cumhuriyet'in ilk yıllarında mimar - sanatçı işbirliği içerisinde yapılan çalışmalardır. Seramik Panoların üretimi, kamu kurumlarının, özel işletme ve otellerin düzenlemiş oldukları proje yarışmaları ve kurumların isteği doğrultusunda çağrılı sanatçıların projelerini uygulamaları ile gerçekleşmekteydi. Jale Yılmabaşar bu prensipler doğrultusunda pek çok kurum için seramik duvar panoları çalışmışır. Panolarında, rengârenk bir tablonun estetik misyonuyla, çamurun birlikteliğini ve uyumunu yakalayan sanatçı; bir kültür harmanlaması içerisinde sanatsal değeri ve kültürel kimliğini yansıtmaktadır. Yüzeyin renklenmesi ve sırlanmasında imgelerin asıl zenginliğini ortaya çıkaran Yılmabaşar eserlerinde, çalışmıs olduğu farklı teknikler ve yarattığı sanatsal çizgi ile, bitmez tükenmez bir çalışma performansı sergileyerek, çalışmış ve üretmiştir. Kendine özgü teknik ve özgün betimlemeleri ile proje tasarımlarını hazırlayıp, sonrasında da uygulayan Jale Yılmabaşar, panolarında Anadolu'nun zengin kültür birikiminden faydalanarak, bu birikimi kendine has motiflerle harmanlayıp çalışmalarında kullanmıştır. Bu nitelikleriyle de Cumhuriyet dönemi çağdaş Türk seramik sanatının öncü sanatçıları arasına girmiştir.

Bu makalede Jale Yılmabaşar'ın mimari mekânlardaki seçili, iç ve dış mekân seramik duvar uygulamaları üzerinden, sanatçının panoları hakkında genel bir bilgilendirme ve değerlendirme yapılması amaçlanmaktadır.

Anahtar Kelimeler: Seramik, Sanat, Seramik Duvar Panosu, Mekân, Jale Yılmabaşar.

\footnotetext{
${ }^{1}$ Öğr.Gör.Dr.Bengütay HAYIRSEVER ,Erciyes Üniversitesi, Güzel Sanatlar Fakültesi Seramik ve Cam Tasarımı Bölümü, Kayseri, ORCID:0000-0001-5247-533X, bengutay-26@hotmail.com
} 


\title{
JALE YILMABAŞAR AND AN EVALUATION ON SELECTED CERAMIC WALL PANELS
}

\begin{abstract}
Ceramic wall panels used in architectural spaces add a distinct value and aesthetics to the building. Indoor and outdoor ceramic wall panels where Jale Yilmabaşar Works are among the leading works of contemporary Turkısh ceramic art.Ceramic panels are Works done in collaboration with architects and artists in the early years of the Republic. The production of ceramic panels was carried out by the Project competitions organized by public institutions, private enterprises and hotels and by the applications of the invited artists in line with the requests of the institutions. Jale Yllmabaşar has worked with ceramic wall panels for many institutions with these principles. Bringing the aesthetics of a colorful painting and mud together on her panels, the artist reflects her cultural identity in her works. Highlighting the images in the coloring and glazing of the surface, Yılmabaşar has produced her Works with a unique artistic understanding. Drawing her designs with her unique techniques and uniqueinterpretations and working on ceramic applications, the artist was inspired by the rich culture of Anatolia on her ceramic panels. The artist skillfully used Anatolian culture and unique motifs together, and with these qualities, she became one of the leading artists of the Republican period contemporary Turkish ceramic art.

In this article, it is aimed to give a general information and evaluation about jale Yılmabaşar's selected ceramic wall panels in architectural spaces.
\end{abstract}

Keywords: Ceramic, Art, Ceramic Wall Panel, Space, Jale Yılmabaşar.

\section{Giriş}

Mavi, Turkuaz, Sarı... Bu renklerdeki sırların, kendisi için ateşte renklerin dansını, yaşamı ve canlılığı ifade ettiğini belirten Jale Yılmabaşar'ın sanat tutkusu, babası yüksek mühendis Bahattin Yılmabaşar'ın gramofon plaklarını sıcak suda eriterek onlara form verebileceğini keşfetmesiyle başlamıştır. Bu girişim gelecekteki mesleğine de ilk adımlarını atmasını sağlamıştır. (Ulueren, 2005, s.93)

1939, Samsun doğumlu olan Jale Yılmabaşar, İlk seramik çalışmalarına 1957 yılında, Oregon'ın Albany kentinde başlamıştır. Atatürk Kız Lisesinde öğrenciyken kazandığ1 A. F. S Bursu ile A. B. D de 1 yıl eğitim görmüş, daha sonra 1958 yılında Devlet Tatbiki Güzel Sanatlar Yüksekokulu Seramik Bölümü'nü kazanarak Prof. Hakkı İzzet'in öğrencisi olmuştur (Y1lmabaşar, 1980, s.8). 


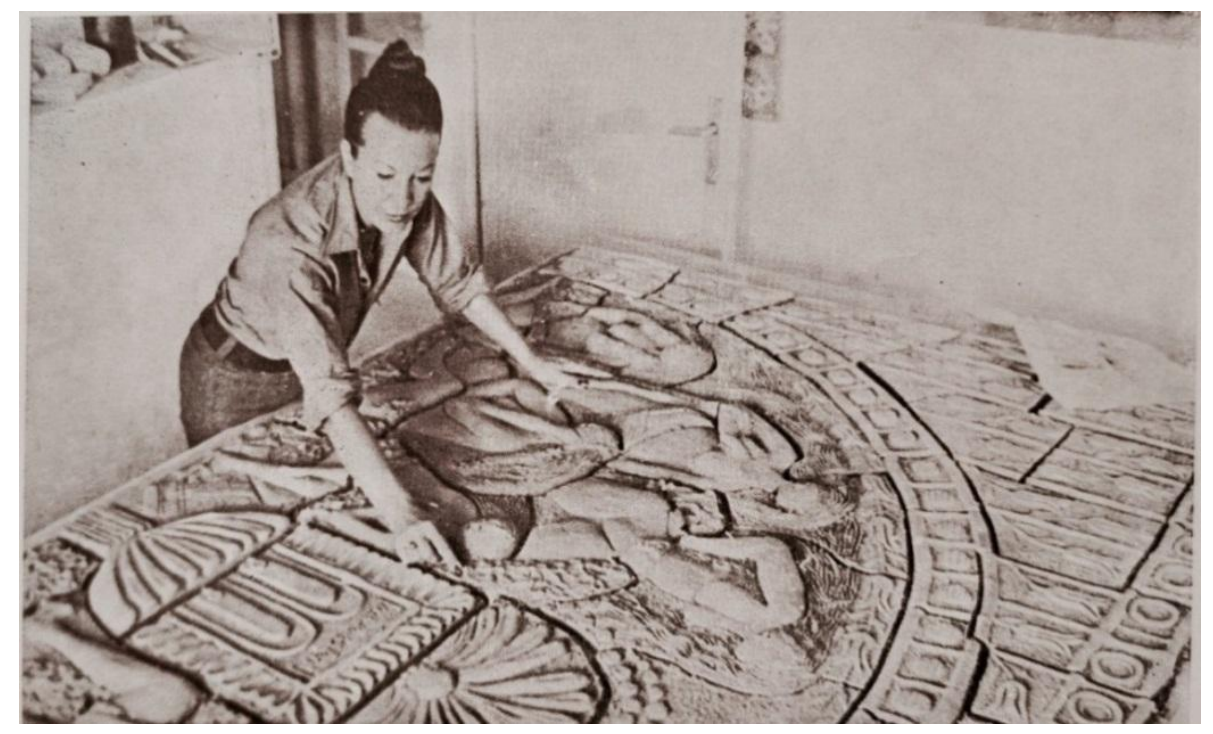

Görsel 1. Jale Yılmabaşar. (Yılmabaşar , 1980 s. 140) (Kaynak: Yılmabaşar, J (1980). Jale Yılmabaşar Seramikleri Yöntemleri, Türk Tarih Kurumu Basımevi, Ankara. s 140)

1966 yılında mezun olduğu okuluna Öğretim Görevlisi olarak tekrar dönen sanatçı ; "1985 yılında Fatih Sultan Mehmet Köprüsünün ayakları, atölyemin üzerinden geçtiği için atölyem istimlak edildi. Bu olay nedeni ile çok üzüldüm ve İstanbul'dan ayrılmak istedim. Marmara Üniversitesi Güzel Sanatlar Fakültesi Seramik bölümündeki görevime ara vererek Münih Devlet Güzel Sanatlar Akademisinde Resim ve Grafik bölümlerinde derslere girdim. Atölyemin yıkımının üzüntüsü, yaratıcılığımı olumlu yönde etkiledi ve bu durum çalışmalarıma yansıdı, resimlerimin konusu bu tarihten itibaren atölyem, köprü ve horoz oldu" (Cumhuriyet Tarihinin İlk Kadın Profesörü, 2018, s.48 ) sözleriyle sanat hayatına yön veren bir anısını paylaşmıştır. Sanatçının 46 yaşında resim öğrencisi olması, takdir edilecek bir davranış ve hayata azim ve çalışkanlıkla bağlı olmasının yanında daima araştırmacı ve mücadeleci yönünü göstermektedir. (Arna, S .2003, 5 Ocak, sy)

Sanatçı, Marmara Üniversitesi Güzel Sanatlar Fakültesi Seramik Bölümünde Öğretim üyesi olarak uzun yıllar çalışmış ve Türkiye'nin ilk kadın seramik profesörü olmuştur. Yurtiçi ve yurtdışında sayısız kişisel sergi ve karma sergilere katılmış, pek çok önemli ödüller almış, ülkesini sanat platformlarında başarı ile temsil etmiş ve seramik sanatını tanıtmak adına çok önemli bir misyon üstlenmiştir. Gerek Türkiye' de gerekse yurtdışında çok sayıda otel, sanat merkezi, uluslararası kuruluşlarda seramik duvar panosu çalışmaları yer almaktadır.(Gün,B. 2017, 14 0cak, sy)

Jale Yılmabaşar, profesyonel olarak 1963 yılında başladığı ve günümüze kadar kesintisiz bir şekilde sürdürdüğü azmi, çalışkanlığı, uygulanmamış seramik tekniklerini çalışmadaki, araştırmacı kişiliği ile kendini daima geliştiren, çağdaş 


\section{JALE YILMABAŞAR VE SEÇILİ SERAMIK DUVAR PANOLARI ÜZERINNE BIR DEĞERLENDIRME}

Türk seramik sanatına özgün bir bakış açısı getirerek, seramik çalışmalarını farklı sanatsal disiplinlerle bir araya getirmeyi başarmış bir sanatçıdır.

Yılmabaşar, çağdaş Türk seramik sanatında, mimari yapılarda çalışmış olduğu iç ve dış mekân seramik duvar panosu çalışmalarıyla öncülük yapmış sanatçılarımız arasındadır. Seramik duvar panolarında kullanmış olduğu teknikler ve malzeme çeşitliği ile yaratıcı tasarımlarını birleştirmiş ve bu alanda sayısız çalışmalar yapmıştır. Sanatçının üç boyutlu seramik formları, resimleri, duvar panoları, tekstil tasarımları gibi pek çok alanda çalışmaları mevcuttur. Bu makalede sanatçının üç ayrı mekanda yer alan beş panosu seçilmiştir ve bu seramik duvar panoları üzerinde durularak, çalışmaları anlatılacak, seçili panolar üzerinden sanat anlayışı, renk, doku, biçim ve içerik açısından bir değerlendirme ve bilgilendirme yapılacaktır. Sanatçı; 1960' l1 yıllardan itibaren çalıştığı seramik duvar panoları ile ilk örnekleri vermiş, döneminin getirdiği ekonomik zorluklar ve malzeme kısıtlılığına rağmen, üstün bir yaratıc1lıkla, tekniğe hakim bir şekilde özgün tasarımlar ortaya koymuştur. Seramik duvar panolarını zor ve ağır şartlarda çalışılarak, önemli ve kalıcı örnekler vermiştir. Bu bakımından Türk seramik literatürüne kattığı değerler ile büyük önem arz etmektedir. Günümüzde inşaat sektörünün hızla gelişmesi ve değişmesi ile pek çok mekan hızlayıkılmakta ve yerine yeni binalar inşa edilmektedir. Bu binalarda bulunan sanat eserleri ya bina ile birlikte yıkılmakta, yok olmakta yada kırılıp dökülerek harap olmaktadır. Pek çok sanatçı bu konuda mağdur olmuş ve sanat eserleri yıkılıp kaybolmuş, sahip çıkılmamıştır. Yılmabaşar'ın bu makalede anlatılan dört panosu da mevcut bina başka bir mekana taşınırken, sanatçının mekan için özel olarak çalıştığı duvar panoları da, büyük önem ve değer verilerek yeni mekana taşınmış ve onlar için özel alanlar tahsis edilmiştir. Bu örnek davranışlar her sanatçının isteği, düşüncesi ve hayalidir. Tüm sanatçlar sanat eserleri uzun yıllar ilk monte edildiği yerde yaşasın ve pek çok izleyici ile buluşsun ve işleri evrensel olsun ister. Bu bakımdan Yılmabaşar'ın sanat eserlerine verilen değer sanatçılar açısından sevindirici ve ümit vericidir. Kurumların sanat eserlerine verdikleri değer, diğer kamu ve özel kurumlar için örnek teşkil edecek bir davranıştır. Bu panolar özellikle seçilerek, makaleye konu olmuştur.

“Çalışmalarında Hitit dönemi figürleri, horoz, kuş, göz gibi dönemsel ve yöresel motifleri kullanan sanatçının seramik çalışmalarının yer aldığı bazı mekanlar şöyle; Vakko Fabrikası (şu an Vakko Moda Merkezi'nde), Maslak Çarşı girişi, Divan Oteli, Halk Bankası, Hürriyet Gazetesi terası, Türkiye Turing ve Otomobil Kurumu Binası, Yalova'da Aydın Han dış cephesi, Çanakkale Fabrikası, Swissotel Efes İzmir." (Gün, B, 2017, 14 0cak, sy )

Seramik pano yapımında çağdaş Türk seramik sanatında öncülük yapmış olan sanatçının çalışmaları, gündelik hayat ve kamusal alan içinde izleyicilerle buluşmuş, alımlayıcısının estetik dünyasına katkı sunmuştur. Çalışmalarında renkçi üslubuyla, farklı mekanlarda mekana özgü tasarımlarıyla yoğun bir şekilde çalışmalar yapmış 
olan sanatçı; pek çok mimari mekanı sanat eserleriyle donatmıştır. Bu makalede Vakko Moda Merkezi için çalışmış olduğu panoları, Swiss Otel Büyük Efes İzmir için çalıştığı panoları ve Hürriyet Gazetesi için çalışmış olduğu seramik panosu üzerinde durularak, adı geçen mekanlardaki beş seramik duvar panosu üzerinden çıkarımlar yapılacaktır.

\section{Sanatçının Seramik Duvar Panolarından Örnekler}

\section{Jale Yılmabaşar, Vakko Moda Merkezi (Vakko Holding) Seramik Duvar Uygulamaları}

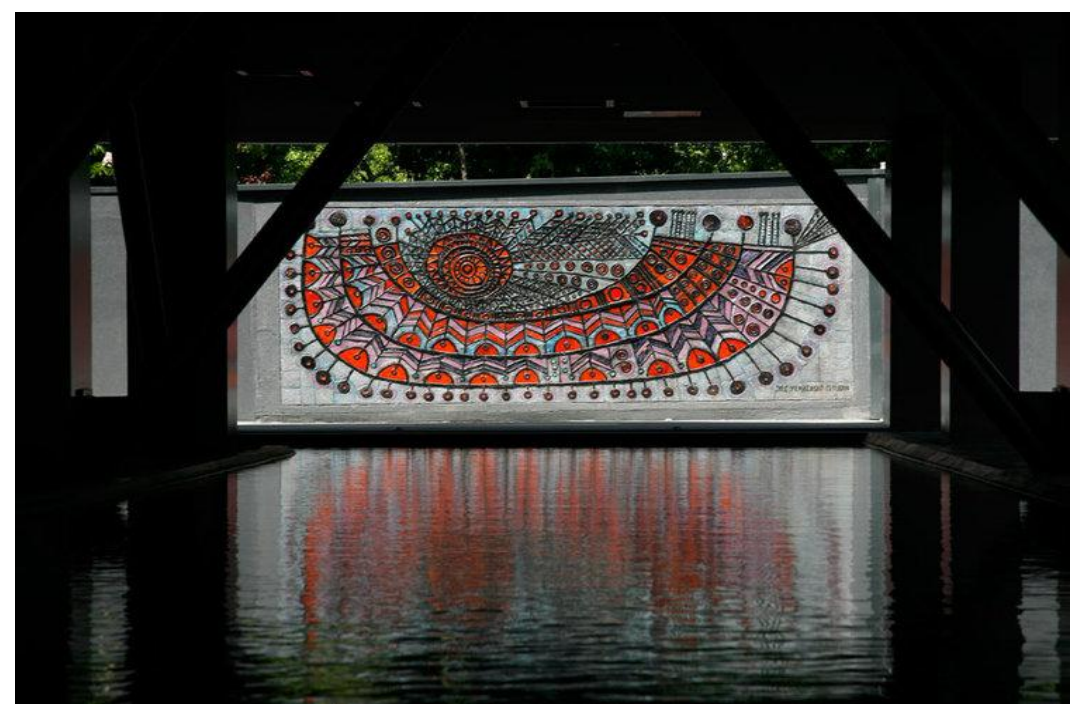

Görsel 2. Jale Yılmabaşar, Vakko Fabrikası, 1969, İstanbul. (Kaynak: http://inbetween.online/tr/things/2017/1/13)

Sanatçının çalışmış olduğu seramik panolarının her birinin ayrı hikayesi bulunmaktadır. Jale Yılmabaşar, Vakko fabrikasının giriş panosunu 1969 yılında tam 6 ay, gece gündüz çalışarak tamamlamıştır.

“Vakko seramik panosunu yekpare çalışmıştım. Yapım sürecinde Ortaköy'deki fabrikada karıştırılmış şamotlu kili yoğurarak masa üstüne bütün panoyu açıım. Altı ay masa üstünde çalıştım. Kurudu, boyadım, harika oldu. Mimar Haluk Baysal'ı çağırıp panonun bitişini gösterdiğimde "Mükemmel, hemen monte edin" dedi. Plakaların montaj sırasında arkasındaki çamurun ufalandığını gördüm. Anlamıştım, fabrikada bana verilen çamuru yoğuran işçiler alçı plakalar arasında kuruttukları için çamura ne yazık ki şamotun dışında yanlışlıkla alçı tanecikleri karışmıştı. Buna çok üzüldüm, panoyu çöpe atıp tekrar yapmaya karar verdim. Çünkü senelerce Vakko'da dış mekanda kullanılacak olan panoya yağmur ve kar altında derzlerden giren sular hasar verirdi. Bu yüzden yeniden yaptım. Panom 40 


\section{JALE YILMABAŞAR VE SEÇILİ SERAMIK DUVAR PANOLARI ÜZERİNE BİR \\ DEĞERLENDIRME}

yıldır hiçbir şey olmadan yerinde durdu. (Arna ,S .2003,5 Ocak ,sy ) Sanatçı, kendi ifadesiyle pano çalışma sürecini böyle dile getirmiştir.

Çalışılacak olan panoda, kullanılacak olan çamurun seçilmesi ve çamurun hazırlanması, uygulanacak teknik, monte edileceği mekan kadar önem arzetmektedir. Bu yüzden de duvar panosu çalışan sanatçılar, bu çalışma sürecinin her anını kendileri yürütüp panolarının hem çamur yoğurucusu, hem uygulayıcısı hem de teknik çözümleyicisi olmaktadırlar. (Görsel 3 -Görsel 4 )

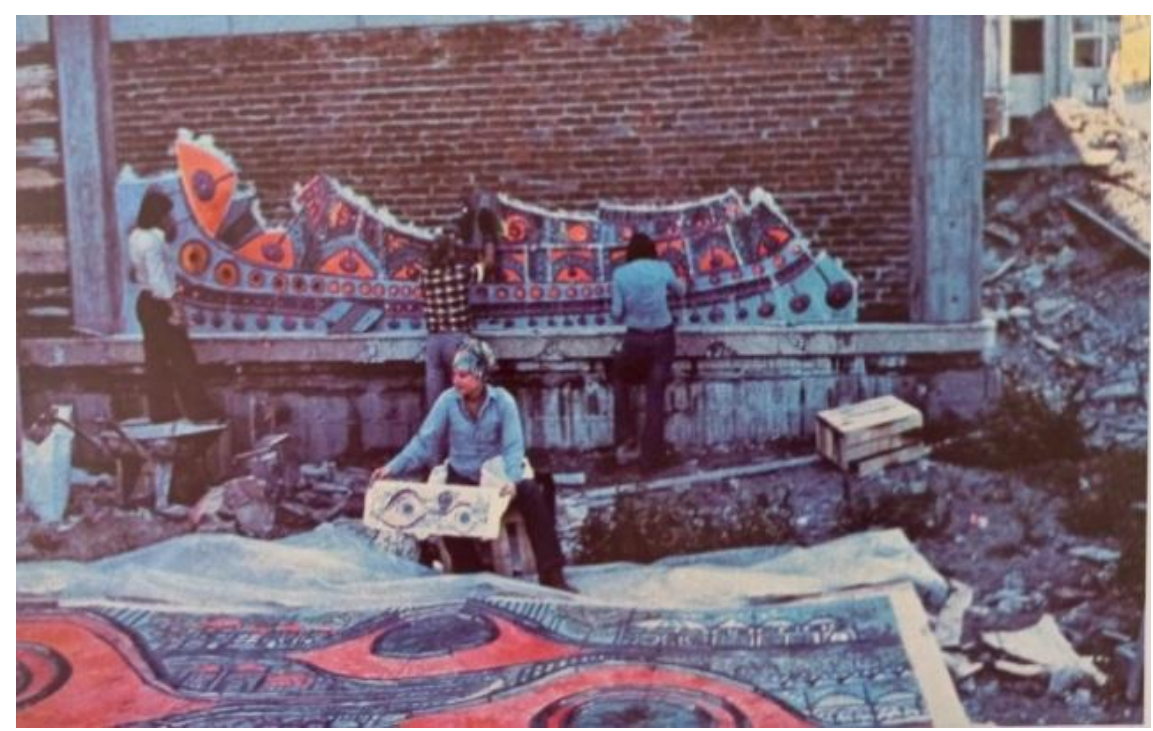

Görsel 3. Pano Monte Aşaması (Kaynak: Yılmabaşar, J (1980 ). Jale Yılmabaşar Seramikleri Yöntemleri. Ankara: Türk Tarih Kurumu Basımevi, s 157.)

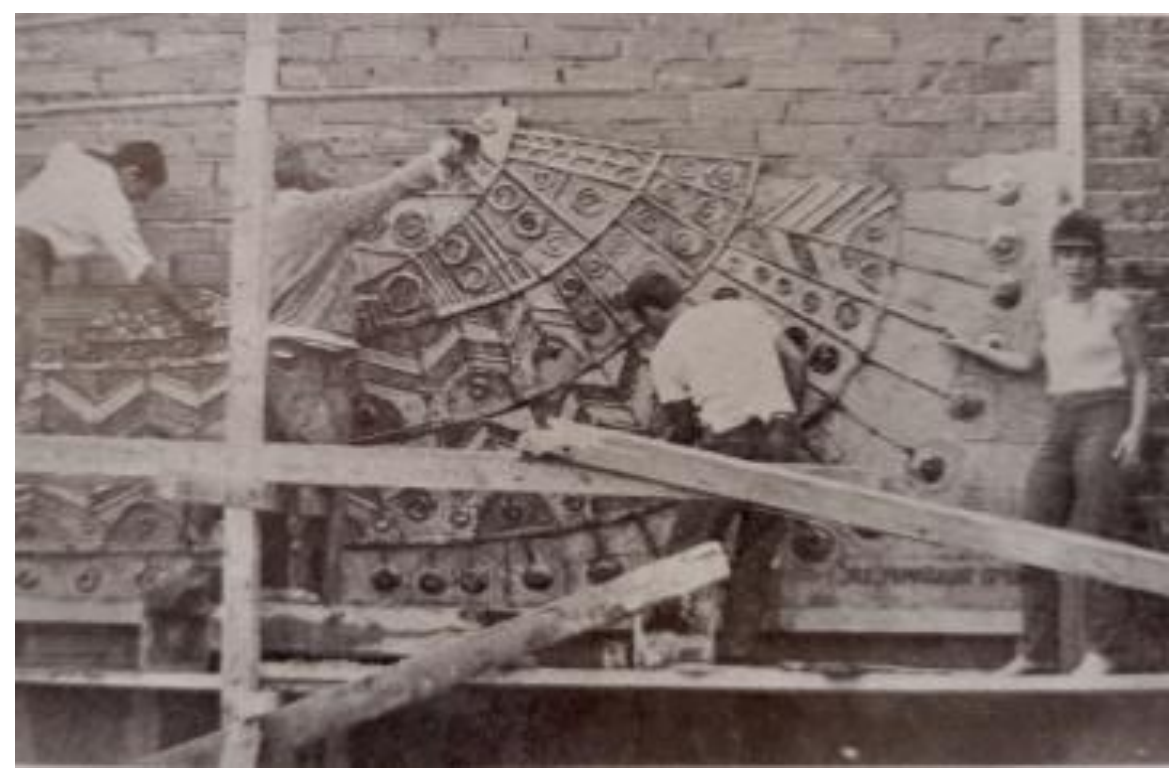

Görsel 4. Pano Monte Aşaması. (Kaynak: Yılmabaşar, J (1980). Jale Yılmabaşar Seramikleri Yöntemleri. Ankara: Türk Tarih Kurumu Basımevi.) 


\section{JALE YILMABAŞAR VE SEÇILİ SERAMIK DUVAR PANOLARI ÜZERINNE BIR DEĞERLENDIRME}

Yılmabaşar (1980, s. 135); Fotografta yapımı görülen pano bir tekstil fabrikasının dış yüzeyine uygulanmıştır. "Yapılacak panonun uygulama tekniği yapılacak yer ve konumu düşünülerek seçilir. Günümüzde seramik duvar panoları iç mimari kadar, Dış mimaride de estetik ve fonksiyonel durumu birlikte düşünülerek uygulanmaya başlanmıştır" (Y1lmabaşar, 1980, s. 135) diyen sanatç1; yol üzerinde olan bu binanın yüzeyine yapılan bu panoda, hızla geçen araçlardan görülebilecek büyük bir motif ve desenler arasında da yakından bakanlar için detaylar uygulamıştır. (Görsel 3 - Görsel 4)

“Her türlü mekanda yer alan seramik duvar uygulamalarl, bireylerin günlük hayatlarını sanat ile harmanlamış, ayrıca psikolojik açıdan pozitif bir enerji katarak kişide olumlu bir alımlama yaratmıştır. Kamusal binalar ve alanlar halka açık mekanlar olduklarından, pano uygulamaları öncelikle bu alanlarda seyirci ile buluşturulmuştur. Sanat eserlerinin kamu binalarında kullanılmaya başlamasıyla 1970'li yıllardan itibaren sanata bakış açısında yeni bir algı yaratılmış ve toplumda sanat eserlerine karşı bir farkındalık oluşması sağlanmıştır" (Hayırsever, 2019 , s. 13).

Jale Yılmabaşar mekanlarla sanat eserlerini buluşturmada öncülük yapan sanatçılarımız arasındadır. Yılmabaşar'ın iç ve dış mekanlara uyguladığı yapıtlarında, seramik malzeme üzerindeki hakimiyeti, Çamuru şekillendirme becerisi, imgeleri kullanmadaki ustalık ve panoların mekana göre tasarlama ve teknik çözüm becerisi, dikkat çekmektedir. Sanatçı genellikle Artistik seramik pano uygulamaları çalışmaktadır.

Seramik pano tasarımını, bu tasarımın şekillendirmesini, sırlamasını ve pişirilmesini kendisi gerçekleştiren seramikçi, yaptığı işin niteliğine bağlı olarak hem işin ustalıkla yapılması hem de çıkan işin yaratıcılık bağlamında özgün ve tek oluşuyla sanatçı niteliğini kazanır. Bu tür sanatçı niteliği ile gerçekleştirilen seramik panoları ayırmak ve de vurgulamak için "Artistik Seramik Pano" adlandırılması yapılmaktadır. (Uludağ , 1999, s. 126-127)

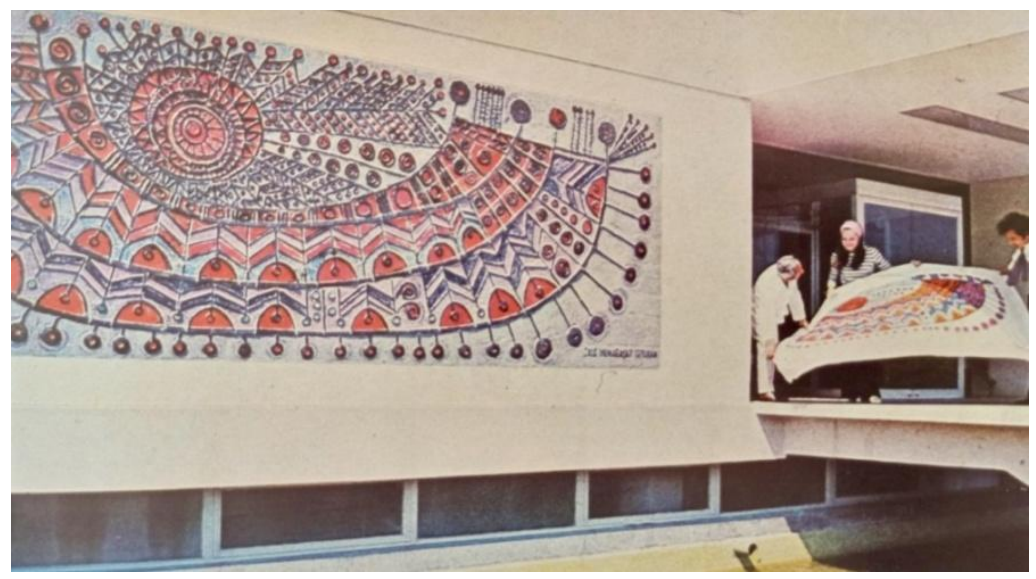

Görsel 5. Vakko Holding, Jale Yılmabaşar'ın Panoyu Monte Etmiş Olduğu İlk Duvar. (Kaynak: Yilmabaşar, 1980, s. 128) 


\section{JALE YILMABAŞAR VE SEÇİLI SERAMİK DUVAR PANOLARI ÜZERINNE BİR \\ DEĞERLENDIRME}

1969'da Merter de açlan Vakko Holding büyük, geniş, yeşillik bir mekanda uzun yıllar hizmet vermiştir. Vitali Hakko, fabrikanın dekorasyonuna çok önem vermiş, dönemin önemli sanatçılarının kapılarını çalarak, onlardan en özel eserlerini fabrikanın duvarlarına yapmalarını rica etmiştir. Jale Yılmabaşar (2), Nevzat Yüzbaşıŏlu (1) ve Bedri Rahmi Eyüboğlu'na (4) ait 7 eser binayı süslemiştir. Bu çalışmalar yıllarca kar kış demeden ayakta durarak mekana estetik bir değer kazandırmışlardır. (Görsel 5) (Gence ,H 2020 ,7 Şubat ,sy). Vakko Holding de, aradan geçen yıllarda nesil değişmiş, işlerin başına oğul Cem Hakko geçmiş, Hakko, üretim tesisini satıp Esenyurt'ta büyük bir binaya taşımış, taşınmanın ardından sıra 100 kişilik tasarım ekibinin yaratıcılıklarını sergileyeceği alanı seçmeye gelmiş, mobilyaların ve eski makinelerin bir kısmını önceki binada bıraktıysa da duvarlardaki sanat eserlerinin terk edilmesine gönlü razı olmamıştır.

"Fabrikaya ilk gittiğimde çok gençtim ve sanattan da biraz uzaktım. O zamanlar babamın vizyonuna çok hayran kalmıştım. Babam bütün duvarları sanat eserleriyle bezemişti. Fabrikamızın hemen girişinde bekçi kulübesinin bulunduğu alanın solunda Bedri Rahmi Eyüboğlu'nun büyük heykeli bizi karşllıyordu. Hemen karşısında Jale Yılmabaşar'ın büyük mozaik eseri vardı. Babam her gün bu eserlere bakarak ve onlara selam vererek binaya giriyordu. Yine onlarla vedalaşarak fabrikasından ayrıliyordu. Bu duvarların, hem Vakko tarihi hem de tüm Vakko tutkunları için çok özel bir anlam ve önemi olduğunun bilincindeydik. Bu nedenle, yeni binamızda da bu eserlere yer vermekararıaldık"(Gün ,B .2017,14 Ocak sy)

Sözleriyle hem eserlerin taşınma sürecinden hem de babasının kuruma katmış olduğu sanatsal imajın ilerleyen yıllarda da devam ettirilmesinde ki çaba ve verdiği uğraştan bahsetmektedir.

Seramik panoların iç ve diş mekanlarda sergilenmesinde, izleyici ve sanatçı açısından mekanın önemi büyüktür. Sanatın en önemli unsurlarından birisi de mekanlardır. Sanat eserleri mekanlarda estetik değer, imaj ve kimlik oluşturmakta önemli bir misyon üstlenmişlerdir. Seramik duvar panoları, mekanın fiziksel boyutuna önemli bir katkı sağlayarak, sadece güzellik katmakla kalmayıp, insanların ruhuna hitap etmektedirler. Seramik duvar panoları özgünlük ve mimariye özgü özel tasarım nitelikleriyle mekandaki izleyicilerin belleklerinde özel bir yer edinmekte ve eserler bulundukları mekanlarla özdeşleşmektedir. Vakko seramik duvar uygulamaları bu düşüncelere örnek teşkil etmektedir. 


\section{JALE YILMABAŞAR VE SEÇILİ SERAMIK DUVAR PANOLARI ÜZERINNE BIR \\ DEĞERLENDIRME}

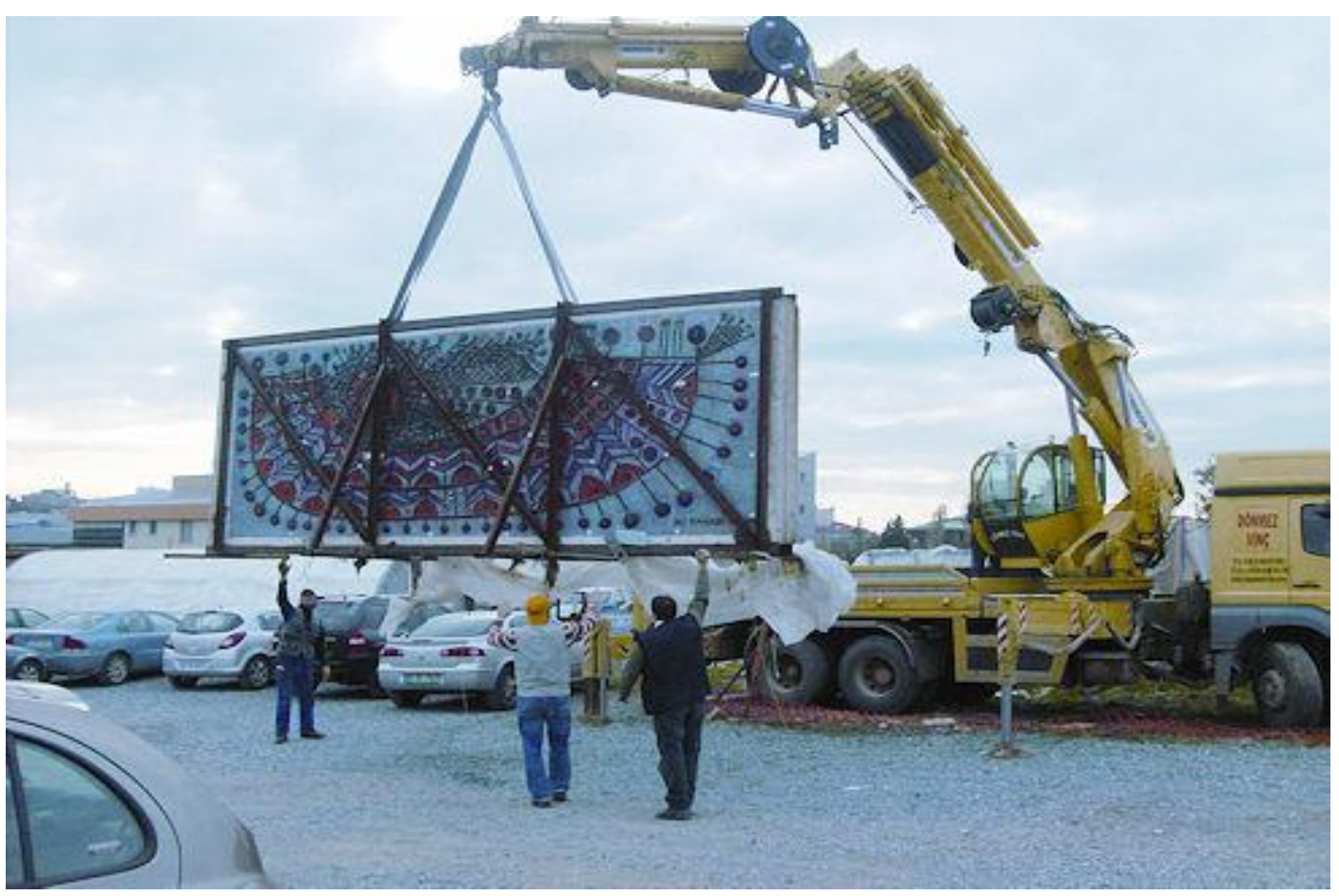

Görsel 6. Vakko Holding Taşınırken Jale Yılmabaşar'ın Panosunun Vinçle Taşınması (Kaynak: Gün ,B 2017,14 Ocak , sy)

Vakko holding fabrikasını Nakkaştepe' deki yeni yerine taşırken Vitali Hakko tarafından yaptırılan seramik duvar panoları da teknolojik imkanlarla taşınmıştır. (Görsel 6) Panoların taşınma süreci; Gence, H (2020), tarafından şu şekilde anlatılmaktadir.

“Önce duvara monte edilmiş bu eserler, lazer yardımıyla duvardan kesildi. Rahat taşınabilir hale gelmeleri için duvar kalınlıkları inceltilerek 10 santime kadar düşürüldü. Çok büyük alan kaplayan eserler, bloklar halinde parçalara ayrılarak taşındı. Arka bölümleri lame demirden çelik kafeslere alındı. İstanbul Üniversitesi' nin konservasyon öğrencileri de çalışmalara yardım etti. Ve nihayet müzeciliğe uygun şekilde yeni mekâna entegre edildi" (Gence , H .2020 ,sy)

Bütün bu işlemler Vakko Holding için, yeni sanat eserleri almaktan daha pahalıya mal olmuş, fakat burada sanat eserlerine verilen değer ve önem, sanatçıların emeklerine duyulan saygı gerçekten çok önemli ve takdir edilecek bir davranıştır. 


\section{JALE YILMABAŞAR VE SEÇILİ SERAMIK DUVAR PANOLARI ÜZERİNE BİR \\ DEĞERLENDIRME}

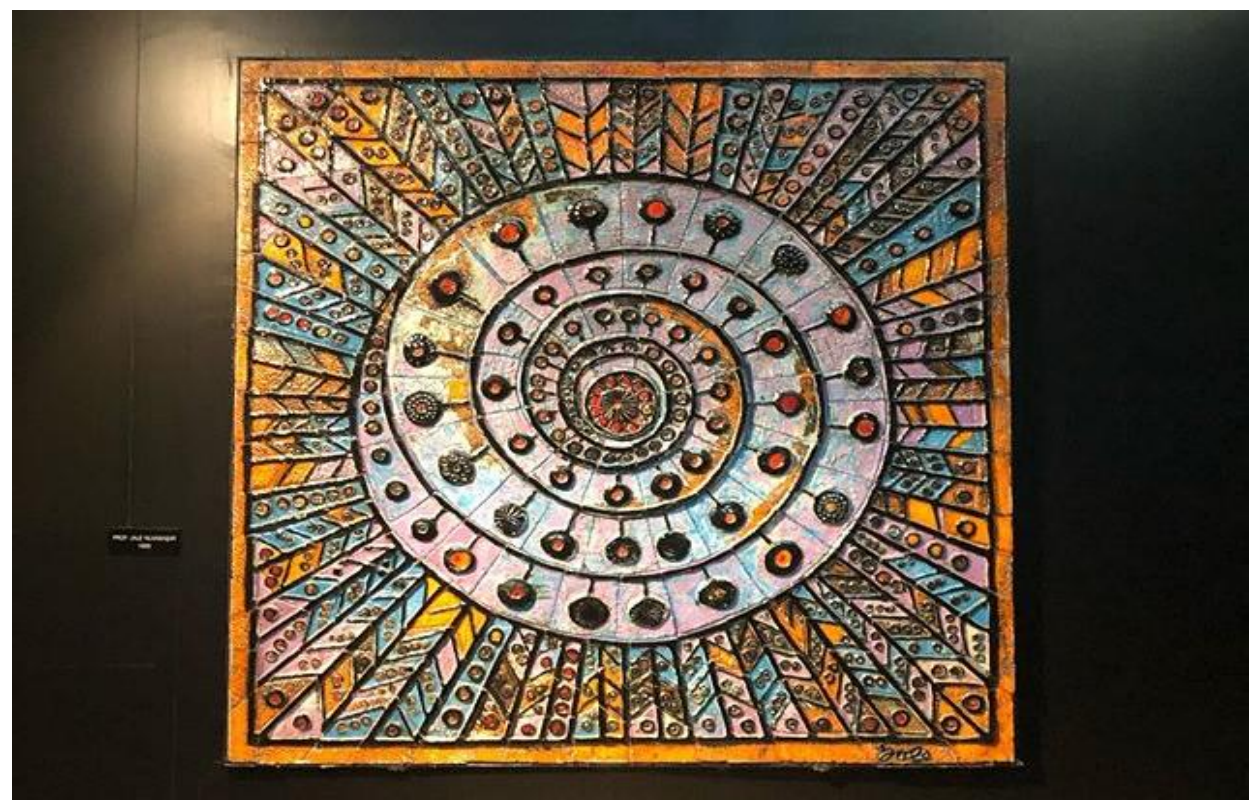

Görsel 7. Jale Yilmabaşar, Vakko Moda Merkezi, İstanbul (Kaynak: https://gramho. com/explore-hashtag/vakkomodamerkezi Erişim: 20.05.2020)

Jale Yılmabaşar'ın Vakko Moda Merkezi için tasarlamış olduğu her iki panoda da panolar içerik ve biçim olarak benzerlik ve bütünlük sağlamaktadır. Her bir panonun kendine özgü bir şekilde tasarlanmış olması önemlidir. Yılmabaşar bir röportajında "Seramik pano, karşıdan bakıldığında bir tablo gibi görünmeli. Bir seramik sanatçısının yaptığı işlerin kalıcı olabilmesi için, iyi bir teknik bilgiye sahip olması gerekir. (Gün ,B .2017,14 Ocak ,sy ) ifadesini kullanmıştır. Sanatçının da bahsettiği gibi panolar adeta bir tablodur. Sanatçı nazar, uğur simgesi göz ve horoz ile cennet kuşu gibi geleneksel motifleri panolarında sıkça kullanır(Özbay, 2014:85). Sanatçının özellikle bu kurum için çalışmış olduğu panolarda, panoya hareket kazandırmak amacıyla Tavus kuşunun kanatlarını andıran bezemelerinde antik Hitit motiflerine benzer motifler kullandığı gözlenmektedir. Panolarında imgelerin asıl zenginliğini ortaya çıkaran sanatçı ; biçimsel rölyeflerin algılanmasında ve yorumlanmasında, renklerin coşku ve çeşitliliğini, çok etkileyici ve belirleyici olarak kullanmıştır. Fabrika taşınmadan önce ilk monte edildiği mekan dış mekan olan seramik pano, fabrika taşındıktan sonra yeni mekana taşındığında iç mekana monte edilmiş ve 1şıklandırma sistemiyle aydınlatılmıştır. (Görsel 2) Aydınlatmanın etkisi ile renk ve 1şık efektleri oluşmuş, farklı bir çarpıcılık ve görsel şölen sağlanmıştır. Diğer seramik pano da müze bölümünde sergilenmektedir. (Görsel 7) Her iki panoda da kullanmış olduğu canlı renkler adeta yaşamı simgelemekte ve panoya hareketlilik katmaktadır. Kullanılan motiflerin biçimsel etkileri izleyicinin algılamasına göre değişiklik göstermektedir. 


\section{Jale Yılmabaşar, Swis Otel Büyük Efes İzmir, Seramik Duvar Uygulamaları}

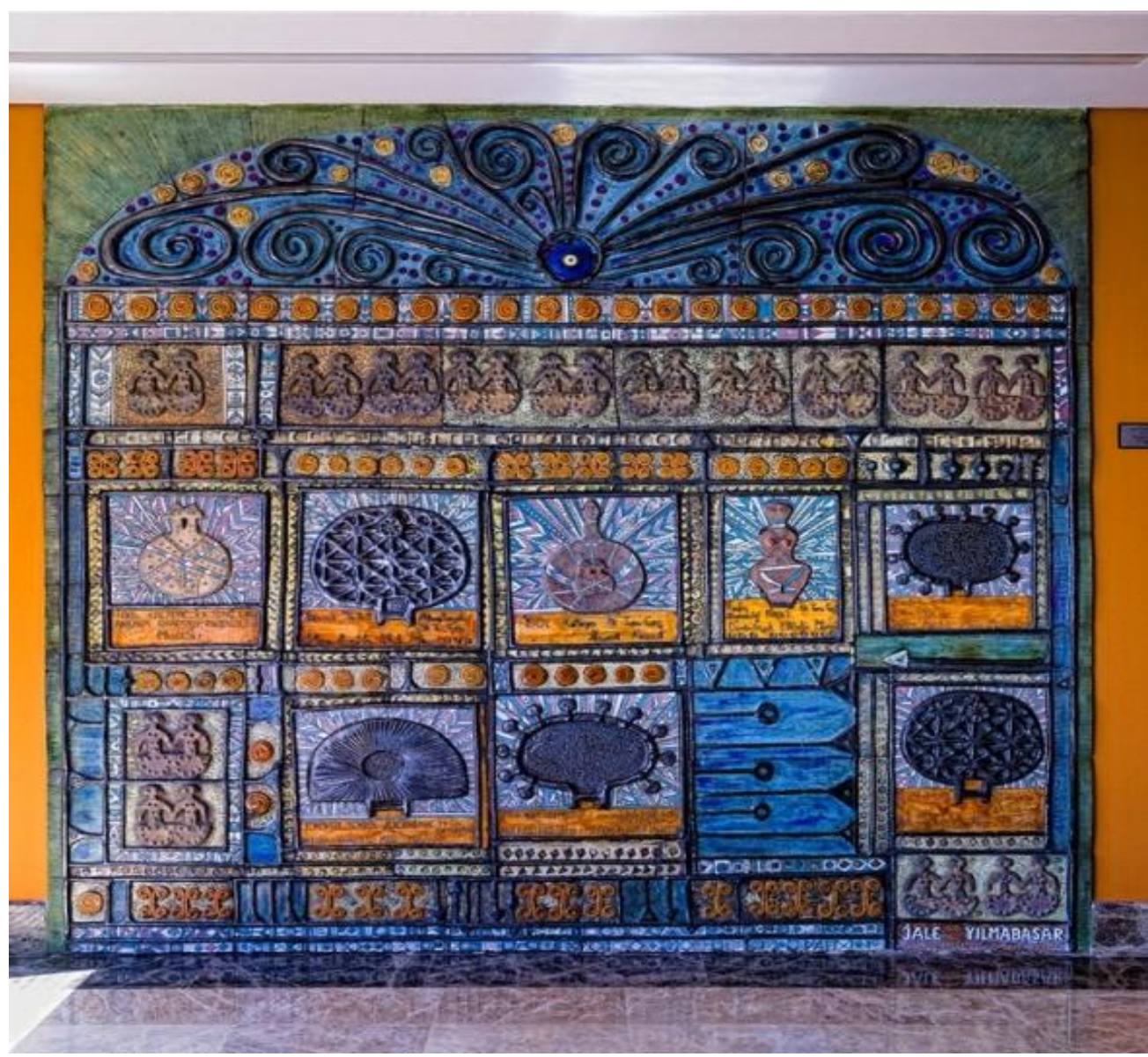

Görsel 8. Jale Yılmabaşar, Swiss Otel Büyük Efes İzmir Seramik Duvar Panosu, İzmir / Türkiye. (Kaynak: http://www.buyukefessanat.com/tr/artist/jale-yilmabasar_28_260. html Erişim Tarihi 22.05.2020)

"Sanat nesnesinin uygulandığı mekanın kimliği (mimari, fiziksel, sosyolojik, psikolojik, vb. kimliği), bütünleşik bir çerçevede değerlendirilmektedir. Bu yüzden sanatçının yaşadığı yaratım süreci, yaratımın kendisi, sergilenme ve algılanma biçimi kaçınılmaz bir şekilde eserin yapıldığı ve sergilendiği yerle ilişkilidir. Sonuç olarak günümüz sanatında 'mekan', sanatı, sanatçıyı ve izleyiciyi etkileyen güçlü bir değişken olmuştur. (Uysal, 2009 , s. 40)

Yılmabaşar, her zaman yaşama ait imgeler kullanan, kişisel olarak da duyarlı ve çok yönlü bir sanatçı kişiliğine sahiptir. Çalışmalarında beslendiği kaynak hayatın kendisidir. Yaşam içerisinde var olan hikayesinde, kendi gerçeklerini ve yaşanmışlıklarını sanatı ile bütünleştirerek izleyiciye sunmuştur. Sanat eserlerinin temel amacının, izleyici de estetik duygular ve kaygılar oluşturmak olduğunu düşünürsek, sanatçının her bir panosunda izleyicisine ayrı bir estetik iletide bulunduğu gözlemlenmektedir. "Bu eser ne diyor? Genellikle çözümleyemediğimiz, ne anlattığını kavrayamadığımız bir yapıtı red ederiz, sanat eseri olarak algılamayız. Kimi zamanda çözümleyemesek bile 


\section{JALE YILMABAŞAR VE SEÇİLI SERAMİK DUVAR PANOLARI ÜZERINNE BİR DEĞERLENDIRME}

duygusal bă̆ kurarız, beğenebiliriz."(Erinç, 2013, s. 95). İzleyici, bir sanat eseri ile karşı karşıya geldiğinde duygusal bir bağ hissederek bir arayışa girer, kendinden bir şeyler bulursa kendini esere ait hisseder. Sanat eserine konu olan sahneler, imgeler, renkler, malzeme kullanımı, izleyicinin kendi dünyasında eseri beğenmesine yada tedirgin olmasına neden olabilmektedir. Jale Yılmabaşar'ın eserlerinde izleyici; kendisine ait imgeler, kültürel motifler ve yerel kodları bularak, kullandığı canlı renkli sırların etkisi ile de psikolojik olarak rahatlama ve mutluluk hissi yaşamaktadır. Sanatçı, otel için çalıştığı panolarında, kendine has betimlemeleriyle, çoğunlukla Hitit motiflerini yorumlamıştır. Hitit uygarlığının ve sanatının simgesi olan güneşi simgeleyen ve yarım daire şeklinin üzerinde barışı, üretkenliği, doğayı simgeleyen unsurlardan oluşan Güneş kursu, bereket, doğum, doğanın canlanışı ve yeşermesini simgeleyen Ana tanrıçayı simgeleyen idol ve ikiz idoller farklı şekil ve renklerde sanatçının kendine özgü yaratıcılığı ile özgün bir tasarım ve renk anlayışı içerisinde izleyiciye sunulmuştur. Hitit motiflerinde kullanmış olduğu renkler, motifleri kucaklayan ikiz idollerin sunumu ve renkleri, yüzeyde kullanılan imgelerin oluşturduğu etkili algı, izleyici de panoya dokunma ve adeta dokunarak tarihi hissetme duygusu yaşatmaktadır. İzleyicide, mekanla bütünleşen panolarda kullanılan imgelere karşı, bir ilgi ve sevgi duygusu oluşmaktadir.

Sanatçı kendi sözleriyle Büyük Efes Oteli'nin panolarının yapım sürecini şöyle anlatmıştır;

“Büyük Efes Oteli yarışması için Türkiye'nin tanınmış sanatçıları Bedri Rahmi Eyüboğlu, Nuri İyem, Nasip İyem, Eren Eyüboğlu, Erdoğan Ersen, Cevdet Altuğ, Füreya Koral, Devrim Erbil, Salih Acar, Atilla Galatalı, Sadi Çalık, Cevat Şakir Kabaağaçlı ve ben İzmir'e davet edildim ve bilgiler verildi... Bu panoyu hazırlarken yine talihsizlikler yaşadım. Çünkü ilk kez bana yardım eden asistan arkadaşlardan çamuru yoğurmalarını istemiştim. İşte sonucu; dört ay ince detaylar çalıştı̆̆ım panomun içine plastik, naylon parçalarını karıştırdıkları için bütün emeğim boşa gitmişti. Atıp, yeniden yaptım. Naylon parçaları alçı veya yabancı cisimlerin kilçamurun içine girmesi ya da hava boşluğu panonun fırında patlamasına ve eserin kırılmasına neden olur. Bu yüzden çamuru hep kendim yoğurmuşumdur." (Arna, S.2003, 5 Ocak, sy) 


\section{JALE YILMABAŞAR VE SEÇİLI SERAMIK DUVAR PANOLARI ÜZERINEE BİR \\ DEĞERLENDIRME}

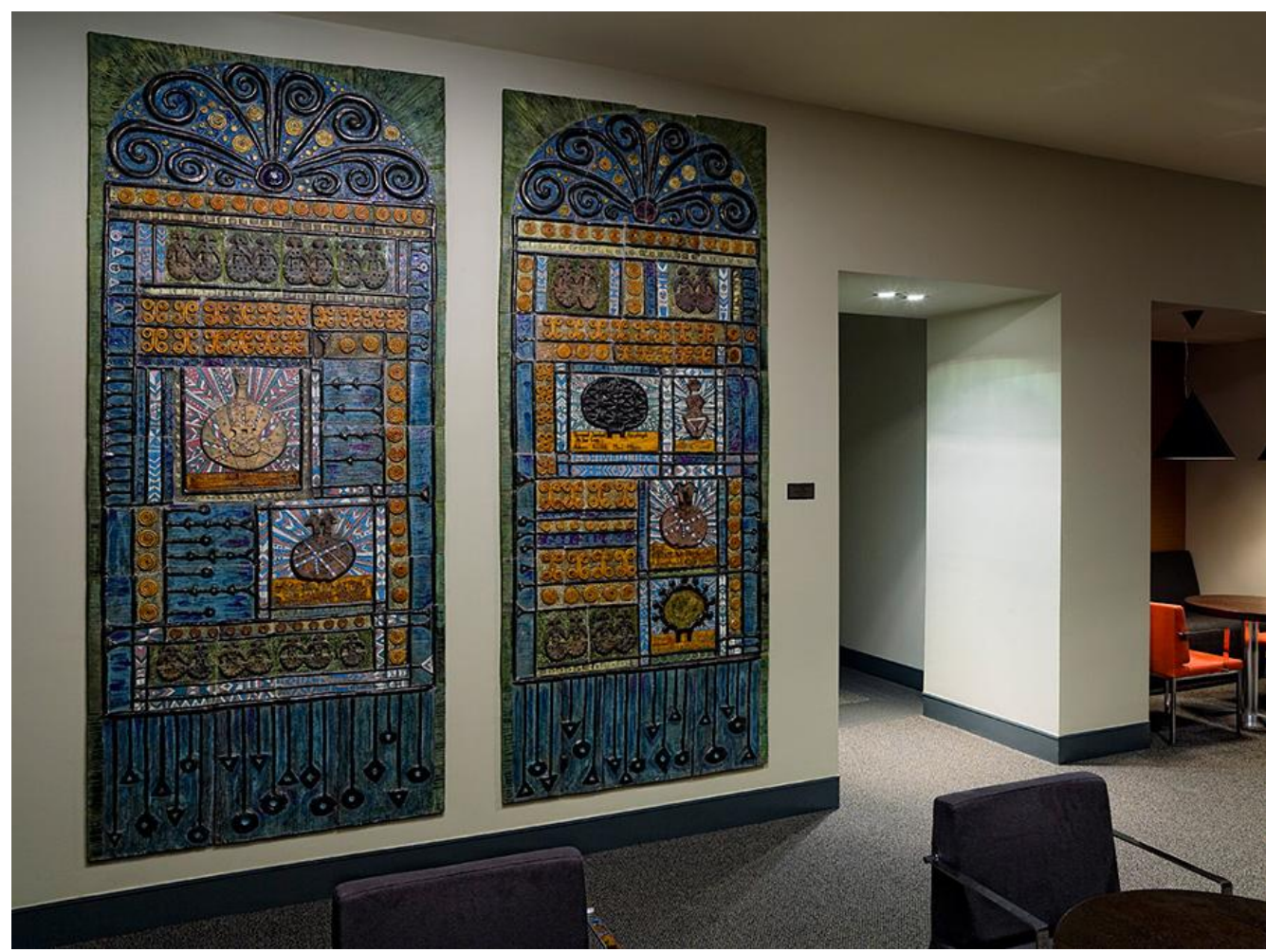

Görsel 9. Jale Yılmabaşar Seramik Duvar Panosu, Swiss Otel Büyük Efes İzmir, İzmir / Türkiye (Kaynak: http://www.buyukefessanat.com/tr/artist/jale-yilmabasar_28_260. html (Erişim Tarihi 25.05.2020)

Bütün yaptığı işlerde, geleneksel ile moderni ; kültürel olan ile güncelin uzlaşısını estetik bir yaratıcılıkla, buram buram Anadolu kokan, geçmişin izlerini çağcılın renklerine büründüren sanatçı, canlı ve çarpıcı eserler üretmiştir.

“Jale Yilmabaşar'ın eserlerine bakarken çıkış noktasında Anadolu kültürünü kolayca görebiliriz. Çizgileri ve motiflerinde geçmiş kültürlerin izlerini, renkleri ve canlılığ1 ile de onun Anadolu'sunu yansitırlar." (Aslıtürk , 2014 , s. 267).

Swiss Otel Büyük Efes İzmir Genel Müdürü Rıza Elibol ; Tarihi Büyük Efes Otel yenilenirken 23 sanatçının eseri korunarak, otel içinde yeni yerlerine konmuştur. Kurum olarak sanat eserleri ve sanatsal faaliyetlere büyük önem ve değer vermekte ve korumakta olduklarını ifade etmiştir (Bkz. Buyukefessanat.com , sanatturu).

Swiss Otel Büyük Efes İzmir, kurum yetkililerinin sanat eserlerine göstermiş oldukları saygı ve değerde takdir edilecek bir davranıştır. Ayrıca günümüz de mimari mekanların çok hızlı bir şekilde yıkılıp tekrar inşa edilmesi sürecinde mekanlarda kalıcı olarak monte edilen, sanat eserleri korunamamakta, kırılmakta, zarar görmektedir. Kurumun bu anlayış içerisinde sanat eserlerine sahip çıkması; Pek çok özel ve kamu kurumunun, sanat eserlerini koruma ve gelecek kuşaklara aktarma çabalarına, örnek teşkil edecek bir çalışma niteliği taşımaktadır. 


\section{Jale Yılmabaşar, Hürriyet Gazetesi Seramik Duvar uygulaması}

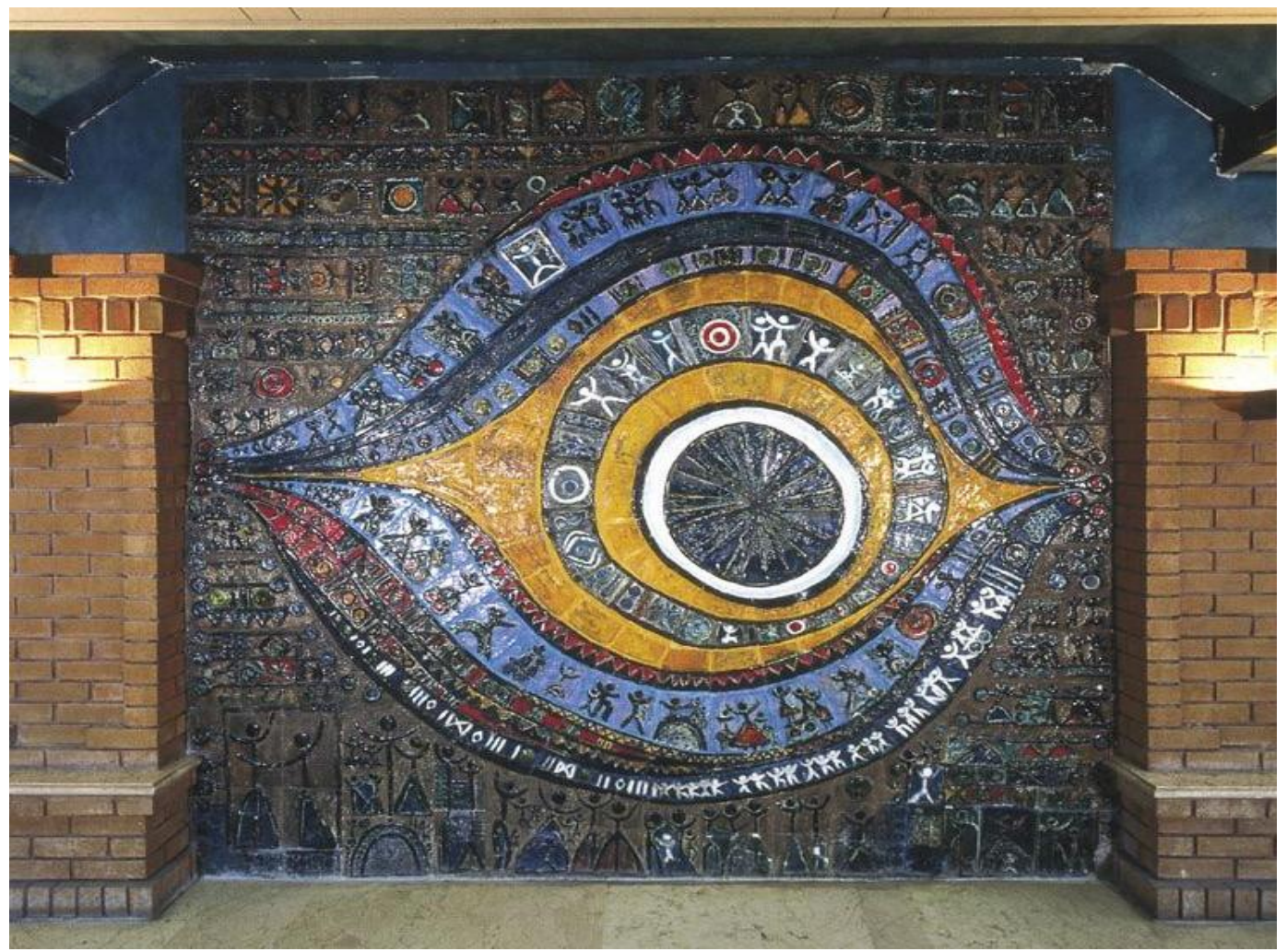

Görsel 10. Jale Yllmabaşar "Göz =Dünyaya Açılan Pencere", 1969, Hürriyet Gazetesi Teras Panosu. (Kaynak: https://www.pinterest.co.uk/pin/297589487874525845/ Erişim Tarihi: 29.06.2020)

Jale Yılmabaşar, Hürriyet Gazetesi için çalışmış olduğu panoda 'Göz' imgesini belirgin bir şekilde kullanmıştır. Göz, hem dünyaya açılan bir pencere hem de nazar değmesine karşı korunmak için bir inanıştır.Sanatçı, göz imgesini canlı renklerle ön plana çıkararak diğer motifleri koyu renkli sırlarla arka planda bırakmış ve perspektif bir etki yakalamıştır. Panoda, canlı renklerle hareketli insan figürleri, dans eden çocuklar, yaşamın ve gündelik hayatın koşuşturması, stilize Hitit motifleri, kimi yerde açık renkli sırlarla kimi yerde de koyu renkli sırlarla renklendirilerek betimlenmiştir. "Sanat eseri yapılmış bir nesnedir, fakat bu salt nesneden hariç, başka şeylerde söyler. Yani eser bizi diğeri ile karşılaştırır, başkayı ifşa eder. Bu bir alegoridir. Yapılmış bir nesne bizi eserde başka olanla bir araya getirir. Eser simgedir.' (Heidegger , 2003 , S.9 )diyen Heiddeger'in söylemini karşılayan işler yapan ve yakaladığı alegoriler ve kullandığı simgelerle alımlayanı eserin içinde başka olanla karşılaştırmanın üstadı Yılmabaşar ; çalışmalarında ilham aldığı konuları şöyle aktarmaktadır.

“Özellikle Anadolu'nun uçsuz bucaksız kültür hazinelerinden ilham alıyorum. Türk motiflerini, çini, halı, çorap, dokuma, tahta oymacılığı, eski köy evlerinde tavan, 
sütun, dolap süslemeleri, yazma, oya ve akla gelmeyen daha pek çok el sanatlarımızda emsali görülmemiş güzellikte ve çeşitlilikte kaynak vardır. Kültürümüz, örf ve adetlerimizde nazara, uğura genelde göz boncuğu kullanıldığı bilinen bir gerçek. Ben de göz ve diğer bir çok motifi bu etkilenmeden dolayı yaptım" (Arna, s. 2003, 5 Ocak, sy)

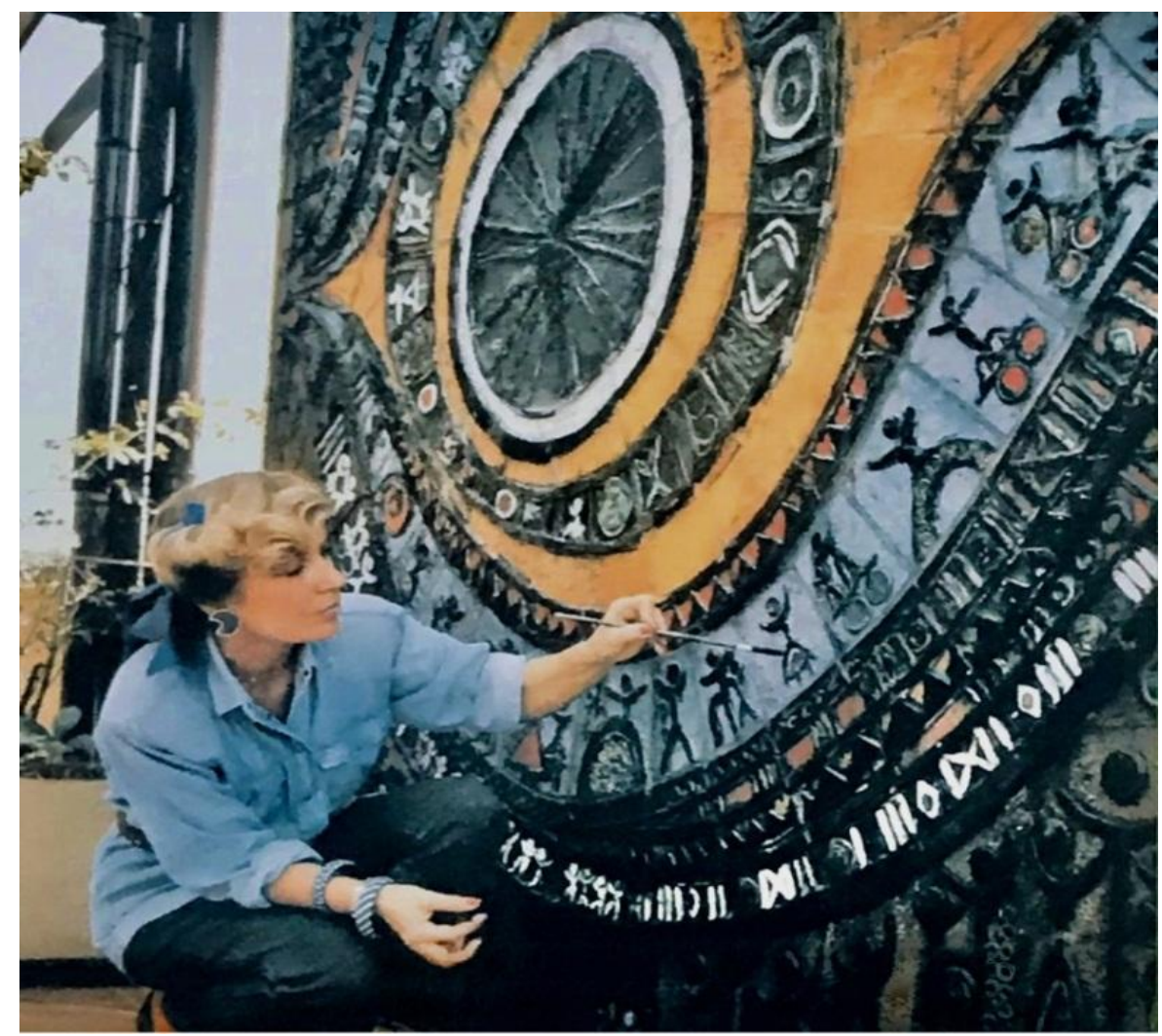

Görsel 11. Jale Yılmabaşar - Hürriyet Gazetesi “Göz" İsimli pano çalışması, Rötuş çalışması (Kaynak: instagram.com/jale.yilmabasar)

Sanatçı kitabında (Yılmabaşar, 1980, s. 155) pano montaj ve rotüş işlemlerinin pano çalışması kadar önem arz ettiğini ve pano montajı yapan ustanın çok deneyimli ve donanımlı olması gerektiğini, kendisinin pano montajlarında yıllardır birlikte çalıştığı ustanın Sait Özbek olduğunu ifade etmektedir. Sanatçı, "Seramik duvar panolarımın tümünün monte edilişinde ben de işçilerle iskele tepesinde bizzat çalıştım. Plakaları numaralarına göre tek tek ben verdim. İş bitinceye kadar onlarla çalıştım"(Arna, S. 2003, 5 Ocak, sy) sözleriyle çalışma sürecinden bahsetmektedir.

Jale Yılmabaşar, çalışmış olduğu tüm panolarda olduğu gibi Hürriyet Gazetesi için yapmış olduğu çalışmada da renk seçimi, kullanmış olduğu imgeler ve çalışmanın mekana uygunluğu ile dikkat çekmektedir. Biçimlerin algılanmasında rölyefler ve renk önemli bir unsurdur. Panonun mekanın bir parçası olarak 


\section{JALE YILMABAŞAR VE SEÇILİ SERAMIK DUVAR PANOLARI ÜZERINNE BİR \\ DEĞERLENDIRME}

algılanması izleyici ile arasında güçlü bir bağ oluşturmakta ve hayatın günlük koşuşturmacası içerisinde rahatlık ve canlılık gibi pozitif duygular ifade etmektedir. Seramik duvar panolarını hem iç mimaride hem de dış mimaride ustalıkla uygulayan sanatçı, mekan tasarımlarında yeni bir anlayış yaratarak döneminin pek çok kurum ve kuruluşuna eserleriyle kalıcı olarak imzasını atmıştır.

Yılmabaşar; çok yönlü bir sanatçı olmasından dolayı, panolarında kullanmış olduğu imgeleri, renkli iç dünyasındaki coşkuyu aynı zamanda tuvallerine de yansıtmıştır.Çalışmış olduğu pek çok seramik duvar panosunu tuvallerinde ,tekstil çalışmalarında hatta araba üzerinde dekor olarak bile çalışmıştır. Sanatçı, Atatürk Kültür Merkezinde 40.sanat yılı münasebetiyle açmış olduğu sergisinde Ford Transit Connected marka bir aracın dış yüzeyini boyamış ve sergide aracın açık arttırmada satılarak gelirinin Türk Eğitim Gönüllüleri Vakfı'na bağışlanacağını söylemiştir.(NTV Arşiv, 2003, 6 Ocak , sy). Yılmabaşar sanat hayatı boyunca da pek çok sosyal sorumluluk projesinde yer almış ve bir çok projeyi desteklemiştir.

Jale Yılmabaşar, gerek eğitmenliği, gerekse de sanatçı kişiliği ve yaratıcılığı ile seramik sanatına sunmuş olduğu teknikleri ile Anadolu kültürünün çizgisinde estetik değerler taşıyan çalışmalar üretmiştir. Toprağın sunmuş olduğu geniş yelpaze ve malzeme çeşitliliğinde anıtsal seramik duvar panoları çalışmış, toprağa kendi iç dünyasını yansıtmış sanatçılarımızdandır. Yılmabaşar'ın seramik duvar panoları ve kullanmış olduğu teknikler gelecek nesillere her zaman örnek olacak çalışmalar ve yöntemler olacaktır.

\section{Sonuç}

$\mathrm{Bu}$ araştırmada, sanatsal üretim ve görsel açıdan Jale Yılmabaşar'ın seçili seramik duvar panoları ele alınmıştır. Özgünlügüün üç ana unsurundan biri olan tasarımın özgünlüğü, kullanılan malzemenin ve çalışmadaki işçiliğin özgünlüğü, mekanların özgünlüğünü desteklemiş ve sanatçının her bir çalışmasında ayrı bir değer kazanarak bulunduğu mekanlar için birer kültürel kimlik oluşturmuştur. Panoların çalışıldığı her binanın mekansal özellikleri bulunmaktadır, eserlerin bulundukları mekanlardaki mekansal ilişkileri temsil etmiş oldukları değerlerle örtüşerek sanat eseri ve mimari bütünlüğü sağlamaktadırlar.

Sanatçı; ister biçimsel, isterse de kullandığı teknikler bağlamında olsun, seramik sanatına, katmış olduğu estetik değerler açısından, kendinden sonraki nesillere ve izleyicisine örnek teşkil edecek eserler ortaya koymuştur. 1960'1 1 yıllarda kent, sanat ve sanatçı ilişkisindeki dengeyi yakalaması, kentleşme olgusuyla birlikte, mekanlarda sanatsal seramik duvar panolarını sergilemesi, Türkiye'de duvar panosu kavramının başlangıcı olmuştur. Kent yapısı açısından yaptığı sanatsal üretimlerinin, aynı zamanda tarihsellik de içermektedir. Sanatçı, 


\section{JALE YILMABAŞAR VE SEÇILİ SERAMIK DUVAR PANOLARI ÜZERİNE BİR \\ DEĞERLENDIRME}

eserlerinde dünü ve bugünü harmanlamış ve bir bütünlük sağlamıştır. Zamanının teknik imkanları içerisinde kentin sanatla olan ilişkisinde estetik ve güzel kavramını izleyicinin algısında yer edindirmeyi başaran sanatçı ;çalışmalarında göz, horoz gibi simgeleri kullanarak, Anadolu kültürünün zengin motiflerini kendine has bir biçimde betimlemiş, işlerini coşku dolu renklerle donatarak sunmuştur. Sanatçı, hangi motifi kullanırsa kullansın çalışmaları hep Anadolu'ya ait ve hep bir öze dönüş, kültürü sahiplenme duygusu yüklüdür. Seramik panolar adeta anıtsal bir heykel ve capcanlı tablolardır. Panolarında hep bir estetik, ritim, hareket ve enerji mevcuttur. Panoların ilk önce resimlerini yapmakta, ondaki renk coşkusu ve hazla, o duyguları ve heyecanı çamura aktarmaktadır. Kendisi de pek çok röportajında bir seramik sanatçısının aynı zamanda iyi bir ressam olması gerekliliğini vurgulamıştır. Seramik duvar panolarının mimarinin ayrılmaz bir parçası olduğunu düşünen sanatçı, her yeni çalışmasından önce mekanı çok iyi gözlemleyip, tasarımını binanın kimliğine göre tasarlayıp, renklendirip, şekillendirmektedir. Çalışılan her panonun ayrı bir hikayesi ve ayrı bir çalışma süreci bulunmaktadır. Sanatçı bütün panolarının yapım sürecinde tasarımından, çamur yoğurulmasına şekillendirmesinden montaj aşamasına kadar üretim sürecini kendi yapmakta ve yürütmektedir. Çalışmış olduğu seramik duvar panoları, pek çok kamu ve özel binalarda, iç ve dış mekanlarda kalıcı olarak sergilenmektedir. Çağdaş Türk seramik sanatında seramik yüzey uygulamaları ile öncülük yapmış olan sanatçının seramik alanındaki çalışmaları hem seramik gönüllüleri için hem de genç sanatçılar için örnek teşkil etmekte ve çalışmaları paha biçilmez değer ve kıymet taşımaktadır.

\section{KAYNAKÇA}

Aslıtürk, E. G (2014). 20. Yüzyılda Türk Seramik Sanatı. Ankara: Gece Kitaplığı.

Erinç, M. S (2013). Sanatın Boyutları. Ankara: Ütopya Yayınları.

Hayırsever, B. (2019). Seramik Yüzey - Mekan İlişkisi ve Bir Duvar Uygulaması. Yayınlanmamış Sanatta Yeterlik Tezi, Dokuz Eylül Üniversitesi, Güzel Sanatlar Enstitüsü, İzmir.

Heıdegger, M. (2003). Sanat Eserinin Kökeni. İstanbul: Babil Yayınları.

Uludă̆, K. (1999). Hamiye Çolakoğlu'nun Artistik Duvar Panosu Tasarımları. Sayı 9, Eskişehir: Anadolu Sanat Yayınları.

Uluderen, D. Ş. (2005). Türkiye'nin İlk Kadın Profesörü, Ateşin Ustası Jale Yılmabaşar, Seramik Türkiye, Seramik Federasyonu Dergisi, İstanbul, Temmuz - Ağustos, No 10.

Uysal, A. M (2009). Sanatta Mekan Algısı. Yayınlanmamış Sanatta Yeterlik Tezi, Hacettepe Üniversitesi, Sosyal Bilimler Enstitüsü, Ankara.

Özbay, B (2014). Artistik Panoların İç Mekan Tasarımına Estetik Katkısı Yayınlanmamış Yüksek Lisans Tezi, Hacettepe Üniversitesi, Güzel Sanatlar Enstitüsü, Ankara.

Yılmabaşar. J. (1980). Jale Yılmabaşar Seramikleri, Yöntemleri, Ankara, Türk Tarih Kurumu Basımevi. 


\section{İNTERNET KAYNAKLARI}

Cumhuriyet Tarihinin Ilk Kadın Profesörü , Jale Yılmabaşar ,2018, s.48 ,http://sed.maestro tr.com/denge_53pdf, $($ Erişim Tarihi 28.03.2020)

Arna,S. (2003,5Ocak,sy). https://www.hurriyet.com.tr/gundem/onu-mutsuzluk-zirveyetasidi-119680 (Erişim Tarihi 05.02.2020)

http://www.buyukefessanat.com/tr/buyuk-efes-sanat/buyuk-efes-koleksiyonu/sanatturu_18.html (Erişim Tarihi 22.05.2020)

Gün, B (2017, $14 \quad$ Ocak, sy). http://inbetween.online/tr/things/2017/1/13/m881h8o3d7yg0wjrh20w5z6brrzmf y (Erişim Tarihi 29.04.2020)

Gence, H (2020, 7 Şubat, sy). https://www.arkeolojikhaber.com/haber-vakko-fabrikasi duvarindaki-rolyefler-lazerle-kesilerek-tasindi-2 (Erişim Tarihi 17.03.2020)

Yilmabaşar'dan Veda Sergisi, 2003, NTVMSNBC, 6 Ocak, http://arsiv.ntv.com.tr/news/195760.asp\#BODY (Erişim Tarihi 04.04.2020) 